\title{
Association between the Percentage of Public Health Efforts Budget Allocation and District Health Office Performances in Depok, 2013 - 2015
}

Fikrotul Ulya and Narita Putri

Faculty of Public Health, Universitas Indonesia, Depok, Indonesia

\section{Abstract}

Health budgeting is one of the subsystems which is included in the National Health System (NHS), where fund extraction, allocation, and expenditure integrated efforts are supporting each other for health development. Health Budget Allocation is used for Public Health Efforts (PHE/UKM), Individual Health Efforts (IHE/UKP), and Other Supporting Efforts. Performance indicator in health sector can be evaluated by observing the accomplishment of Minimum ServiceStandard (MSS) (Standard

Corresponding Author: Fikrotul Ulya

fikrotul.ulya@ui.ac.id

Received: 26 December 2018 Accepted: 23 February 2019 Published: 7 March 2019

Publishing services provided by Knowledge E

(c) Fikrotul Ulya and Narita Putri. This article is distributed under the terms of the Creative Commons Attribution License, which permits unrestricted use and redistribution provided that the original author and source are credited.

Selection and Peer-review under the responsibility of the $2 \mathrm{nd}$ International Meeting of Public Health 2016 Conference Committee. Pelayanan Minimal), which is originated from PHE activities and comparing it towards its target. By increasing the percentage of budget allocation for PHE activities, it is expected that the performance of District Health Office will also be increased. This research aimed to get the information about the percentage of health budget allocation in District Health Office in Depok and its association towards the performance. Thus, this research with the observational study was conducted by using secondary data collected between 2013 - 2015. Bivariate analysis had been done by using correlation test and it showed that there was a significant correlation between the percentage of PHE budget allocation and District Health Office performances in Depok with $r=$ 0.998 (strong correlation) and $p$-value $=0.038$. Therefore, this research showed that the higher percentage of the PHE budget allocation, the higher District Health Office performances in Depok achieved. To conclude, it was great to increase the percentage for PHE budget allocation in purpose to increase the performances of District Health Office in Depok, which would had an impact on the increasing of service standards in the health sector.

Keywords: Health Budget, Public Health Effort, Minimum Service Standard, District Health Office.

\section{Introduction}

Health financing is one of the subsystems in the national health system where there is an attempt of the costing, allocating, and purchasing, which are integrated and support each other in the implementation of health development. Sources of health financing 
come from Government and Non-Government. The mandate of the Health Legislation Number 36/2009 states that the Government health budget in the province and district is allocated a minimum of $10 \%$ (ten percent) of the allocation and budget of the areas outside of the salary. Financing the health budget appropriations are used to finance the Efforts of a public health program (PHE/UKM), individual health program Effort (IHE/UKP) and Supporting Efforts (health systems strengthening/PSK). The third program should be comprehensive and mutual support. The health system is composed of regulatory, governance, human resources health, drugs, health equipment, financing, and health facilities.

In fact, in the year 2015, 20.36 trillion of 51.28 trillion (39.7\%) Health Fund from the Ministry Health Budget were used to JKN program. Permenkes 741/2008 mentioned that the Minimum Service Standard (SPM) was the Health benchmarks the performance of district/city governments in the health field, where 14 of the 18 indicators were derived from the activities of UKM. The health service financing in Depok came from government budget either national or regional. With the greater number of the budget earmarked for UKM, it would hopefully improve the performance of health services.

The synergy of the Central and Local governments in addressing the adequacy of allocation of health financing is indispensable. It is arranged in Kepmenkes 04/2003 in which the Health Accounts ( $\mathrm{HA}$ ) should be developed so that it will retrieve the image of the situation at the level of central funding through the National Health Accounts (NHA), the level of the province through the Provincial Health accounts (PHA) and district/city levels through the District Health accounts (DHA).

This research aimed to describe how to allocate Depok health budget could increase the performance targets of the health office. The benefits of this research was as inputs and the basis for developing a health financing system in the Depok city.

\section{Methods}

This research was an observational study using secondary data collected between 2013 - 2015. Secondary data consisted of the allocation of the budget and coverage of minimum service standard Depok District Health Office in 2013 up to 2015.

The data was analyzed by doing the univariate and bivariate analysis. Univariate analysis was done to get the information about the financial reports and coverage of minimum service standard in the District Health Office in Depok from 2013 to 2015. Bivariate 
analysis was done using the correlation test to get the information between the independent variable and the dependent variable. The independent variable was the percentage of budget allocation activities of UKM and the dependent variable was Depok health service performance in between $2013-2015$.

\section{Results}

The data came from a report on the realization of financial reports and coverage of minimum service Standards (SPM) Depok Health Office. Budget allocation data was further subdivided into:

\subsection{Based on the source of the budget:}

a. District Budget Plan (APBD)

b. Non-APBD, consisting of:

1. Provincial Budget Plan (APBD Provinsi)

2. BOK Fund (Health Operational Assistance)

3. National Healthcare Fund (JKN), including Jamkesmas (Public Health Assurance), Jampersal (Delivery Assurance), and JKN fund.

4. DBHCT (Fund For Tax and Tobacco Results)

5. Tax Smoking Fund

6. Physical DAK (Specific Allocation Fund)

From the table above, it could be seen that most of the budget financing was still a financed by APBD, but there was a trend of reducing APBD because of health budget from the Central Government as the Health Operational Assistance, National Healthcare Fund, Fund For Tax and Tobacco Results, and Smoking Tax Fund.

\subsection{Based on the program of financing of health care, sorted based on the title of the activity:}

1. Public health Efforts (UKM) included community empowerment activities.

2. Individual health Efforts (UKP) included the National Healthcare Fund financing, facilitation of Jamkesda, drugs and supporting services.

3. Health system support (PSK) which included the Management, Facilitation, Infrastructure, and health equipment 
TABLE 1: The Health Budget distribution according to budget in Depok 2013-2015.

Type of Budget
District Budget Plan
Percentage
NON District Budget Plan:
Provincial Budget Plan
Health Operational
Assistance
National Healthcare Fund
Tax Smoking Fund
Fund For Tax and Tobacco
Results
Physical Specific
Allocation Fund
Total Non District Budget
Plan
Percentage
Total Budget
Total District Budget Plan
\% District Budget Plan
\% Non District Budget
\%lan Total Budget

\begin{tabular}{|c|c|}
\hline 2013 & 2014 \\
\hline 92.142.884.276 & 166.554 .021 .845 \\
\hline 79.08 & 72.19 \\
\hline 6.107 .249 .000 & 5.000 .000 .000 \\
\hline 2.758 .800 .000 & 2.950 .800 .000 \\
\hline 6.547 .993 .860 & 31.415 .508 .000 \\
\hline 1.414 .228 .279 & 19.880.782.762 \\
\hline 1.600 .000 .000 & 920.239 .000 \\
\hline 5.944 .183 .100 & 3.991.180.000 \\
\hline 24.372.454.239 & 64.158.509.762 \\
\hline 20.92 & 27.81 \\
\hline 116.515 .338 .515 & 230.712.531.607 \\
\hline 2.358.440.280.976.00 & 2.669.550.591.184.90 \\
\hline 3.91 & 6.24 \\
\hline 1.03 & 2.40 \\
\hline 4.94 & 8.64 \\
\hline
\end{tabular}

\begin{tabular}{|c|}
\hline $\mathbf{2 0 1 5}$ \\
\hline 137.499 .473 .638 \\
\hline 63.60 \\
\hline 4.352 .386 .200 \\
\hline 3.015 .000 .000 \\
\hline 49.494 .419 .048 \\
\hline 17.930 .170 .000 \\
\hline 3.630 .702 .012 \\
\hline 260.261 .500 \\
\hline 78.682 .938 .760 \\
\hline 36.40 \\
\hline 216.182 .412 .398 \\
\hline 3.163 .054 .626 .434 .42 \\
\hline 4.35 \\
\hline 2.49 \\
\hline 6.83 \\
\hline
\end{tabular}

TABLE 2: The distribution of the budget Based on Financing health services in Depok 2013-2015.

Program
UKM
UKP
PSK
TOTAL

\begin{tabular}{|c|}
\hline 2013 \\
\hline Budget \\
\hline 14.416 .372 .979 \\
\hline 75.580 .049 .646 \\
\hline 28.404 .649 .769 \\
\hline 118.401 .072 .394 \\
\hline
\end{tabular}

\begin{tabular}{|c|}
\hline$\%$ \\
\hline 12.18 \\
63.83 \\
23.99 \\
\hline 100 \\
\hline
\end{tabular}

\begin{tabular}{|c|c|}
\hline 2014 & \\
\hline Budget & $\%$ \\
\hline 34.920 .411 .112 & 15.14 \\
\hline 132.494 .523 .836 & 57.43 \\
\hline 63.297 .596 .659 & 27.44 \\
\hline $\mathbf{2 3 0 . 7 1 2 . 5 3 1 . 6 0 7}$ & $\mathbf{1 0 0}$ \\
\hline
\end{tabular}

\begin{tabular}{|c|c|}
\hline 2015 & \\
\hline Budget & $\%$ \\
\hline 37.954 .895 .162 & 17.56 \\
\hline 108.440 .784 .117 & 50.16 \\
\hline 69.786 .733 .119 & 32.28 \\
\hline $\mathbf{2 1 6 . 1 8 2 . 4 1 2 . 3 9 8}$ & 100 \\
\hline
\end{tabular}

From the table and the figure above, it showed that the Depok Health office was working to increase financing for public health efforts and supporting health systems.

Depok Health Office oversaw 35 Primary Health Care Provider (Puskesmas) as the cutting edge of service and activities program. The performance of the health service, referring to the 18 indicators of Minimum Service Standard (SPM) The coverage of activities of the District Health Offices was shown in the following table: 


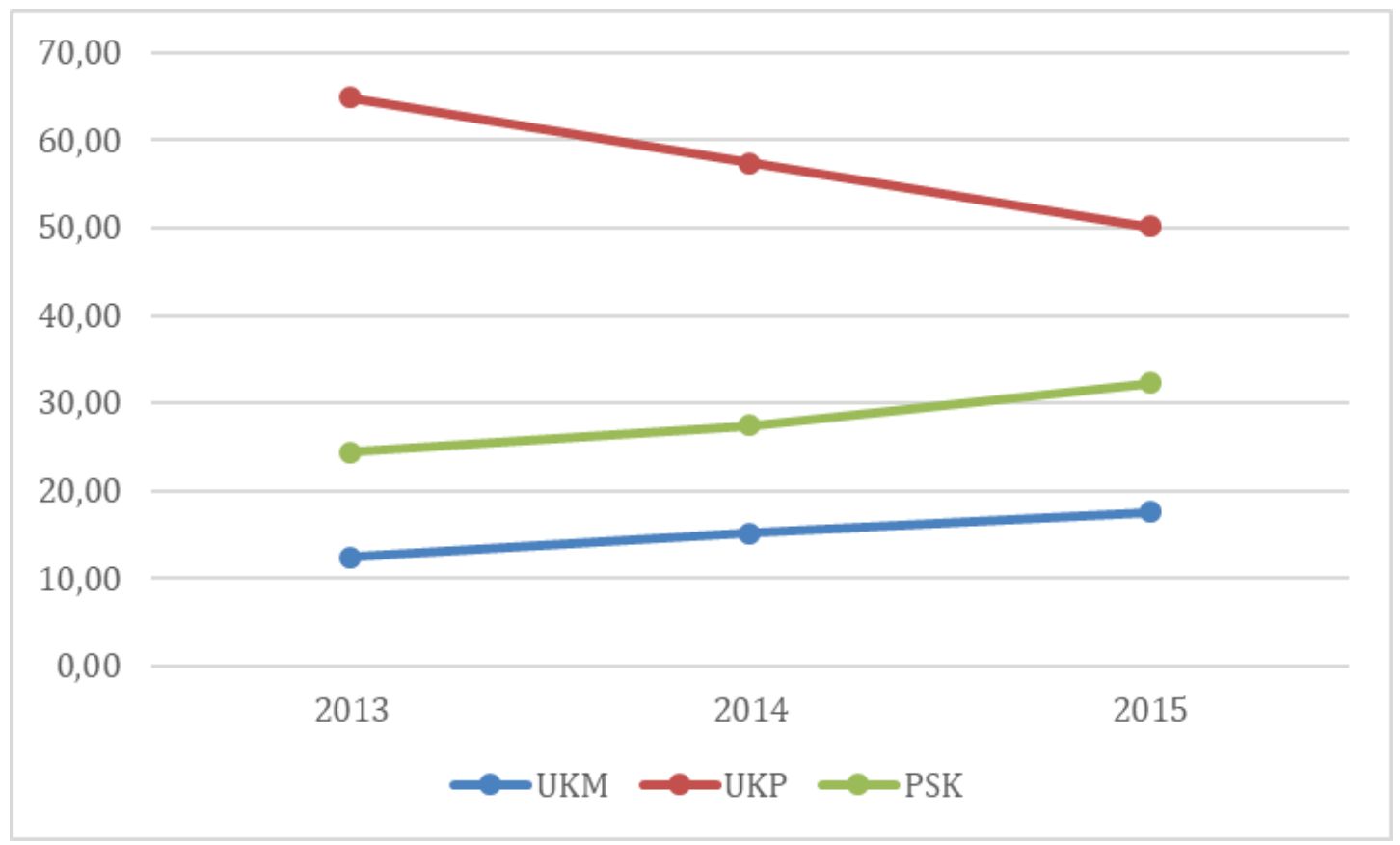

Figure 1: Health service Budget trends Depok 2013-2015.

TABLE 3: Coverage of SPM and the Performance of the Depok Health Office 2013-2015.

\begin{tabular}{|c|c|c|c|c|c|c|c|c|}
\hline \multirow{2}{*}{$\begin{array}{l}\text { Type of Health } \\
\text { Services }\end{array}$} & \multirow[t]{2}{*}{ Indicator } & \multirow{2}{*}{$\begin{array}{c}\text { TARGET } \\
\text { (\%) }\end{array}$} & \multicolumn{3}{|c|}{ COVERAGE } & \multicolumn{3}{|c|}{ PERFORMANCE (\%) } \\
\hline & & & $2013(\%)$ & $\begin{array}{c}2014 \\
(\%)\end{array}$ & $\begin{array}{c}2015 \\
(\%)\end{array}$ & $\begin{array}{l}2013 \\
(\%)\end{array}$ & $\begin{array}{c}2014 \\
(\%)\end{array}$ & $\begin{array}{c}2015 \\
(\%)\end{array}$ \\
\hline \multirow[t]{10}{*}{$\begin{array}{l}\text { Primary Health } \\
\text { care }\end{array}$} & $\begin{array}{l}\text { Visit Pregnant } \\
\text { Women K4 }\end{array}$ & 95 & 91.55 & 93.3 & 9.34 & 96.37 & 98.21 & 99.31 \\
\hline & $\begin{array}{l}\text { Handling The } \\
\text { Complications } \\
\text { The Mother }\end{array}$ & 80 & 100 & 100 & 100 & 100 & 100 & 100 \\
\hline & $\begin{array}{l}\text { Delivery by } \\
\text { trained health } \\
\text { personnel in } \mathrm{PHC}\end{array}$ & 90 & 99.65 & 99.77 & 92.88 & 100 & 100 & 100 \\
\hline & $\begin{array}{l}\text { Service Of } \\
\text { Parturition (KF3) }\end{array}$ & 90 & 84.52 & 83.75 & 88.75 & 93.91 & 93.06 & 98.61 \\
\hline & $\begin{array}{l}\text { Handling Of } \\
\text { Neonatal } \\
\text { Complications }\end{array}$ & 80 & 13.94 & 21.06 & 12.1 & 17.43 & 26.33 & 15.13 \\
\hline & $\begin{array}{l}\text { Visit Baby } \\
\text { Coverage }\end{array}$ & 90 & 97.24 & 94.25 & 100 & 100 & 100 & 100 \\
\hline & $\mathrm{UCl}$ of Village & 100 & 100 & 100 & 100 & 100 & 100 & 100 \\
\hline & $\begin{array}{l}\text { Childhood } \\
\text { Services }\end{array}$ & 90 & 76.86 & 96.99 & 96.94 & 85.4 & 100 & 100 \\
\hline & $\begin{array}{l}\text { The granting of } \\
\text { poor child MPASI } \\
6-24 \text { months }\end{array}$ & 100 & 8.45 & 37.78 & 7.43 & 8.45 & 37.78 & 7.43 \\
\hline & $\begin{array}{l}\text { Stunting nutrition } \\
\text { treatments }\end{array}$ & 100 & 100 & 100 & 100 & 100 & 100 & 100 \\
\hline
\end{tabular}




\begin{tabular}{|c|c|c|c|c|c|c|c|c|}
\hline \multirow{2}{*}{$\begin{array}{l}\text { Type of Health } \\
\text { Services }\end{array}$} & \multirow[t]{2}{*}{ Indicator } & \multirow{2}{*}{$\begin{array}{c}\text { TARGET } \\
\text { (\%) }\end{array}$} & \multicolumn{3}{|c|}{ COVERAGE } & \multicolumn{3}{|c|}{ PERFORMANCE (\%) } \\
\hline & & & $2013(\%)$ & $\begin{array}{c}2014 \\
(\%)\end{array}$ & $\begin{array}{l}2015 \\
(\%)\end{array}$ & $\begin{array}{c}2013 \\
(\%)\end{array}$ & $\begin{array}{c}2014 \\
(\%)\end{array}$ & $\begin{array}{c}2015 \\
(\%)\end{array}$ \\
\hline & $\begin{array}{l}\text { Elementary } \\
\text { School Children's } \\
\text { Screening }\end{array}$ & 100 & 91.93 & 93.19 & 93.26 & 91.93 & 93.19 & 93.26 \\
\hline & $\begin{array}{l}\text { Active FP (KB) } \\
\text { Participants }\end{array}$ & 70 & 76.46 & 75.68 & 74.29 & 100 & 100 & 100 \\
\hline & $\begin{array}{l}\text { The discovery and } \\
\text { treatment of } \\
\text { Sufferers: }\end{array}$ & & & & & & & \\
\hline & $\begin{array}{l}\text { a. } A F P \\
\text { rate/100,000 } \\
\text { under } 15 \text { yo }\end{array}$ & $2 / 100.000$ & 1.527 & 0.561 & 1.659 & 76.35 & 56.1 & 82.95 \\
\hline & $\begin{array}{l}\text { b. Pneumonia } \\
\text { Toddler }\end{array}$ & 100 & 19.09 & 15.01 & 10.50 & 19.09 & 15.01 & 10.5 \\
\hline & $\begin{array}{l}\text { c. New TB } \\
\text { Patients BTA (+) }\end{array}$ & 100 & 55.49 & 45.53 & 53.77 & 55.49 & 45.53 & 53.77 \\
\hline & $\begin{array}{l}\text { d. Sufferers DBD } \\
\text { yg handled }\end{array}$ & 100 & 100 & 100 & 100 & 100 & 100 & 100 \\
\hline & $\begin{array}{l}\text { e. Diarrhea } \\
\text { Sufferers }\end{array}$ & 100 & 74.55 & 79.95 & 84.75 & 74.55 & 79.95 & 84.75 \\
\hline \multirow[t]{3}{*}{$\begin{array}{l}\text { Referral Health } \\
\text { Services }\end{array}$} & $\begin{array}{l}\text { Poor primary } \\
\text { health services }\end{array}$ & 100 & 21.87 & 23.72 & 47.57 & 21.87 & 23.72 & 47.57 \\
\hline & $\begin{array}{l}\text { Referral health } \\
\text { services to the } \\
\text { poor }\end{array}$ & 100 & 100 & 100 & 100 & 100 & 100 & 100 \\
\hline & $\begin{array}{l}\text { Emergency level } 1 \\
\text { services by the } \\
\text { district hospital }\end{array}$ & 100 & 100 & 100 & 100 & 100 & 100 & 100 \\
\hline $\begin{array}{l}\text { Epidemiological } \\
\text { investigation of } \\
\text { the Outbreak and } \\
\text { countermeasures }\end{array}$ & $\begin{array}{l}\text { The Investigation } \\
\text { of the Outbreak } \\
\text { village conducted } \\
\text { epidemiological } \\
\text { act }<24 \text { hours }\end{array}$ & 100 & 100 & 100 & 100 & 100 & 100 & 100 \\
\hline $\begin{array}{l}\text { Health promotion } \\
\text { and community } \\
\text { empowerment }\end{array}$ & $\begin{array}{l}\text { Active Village } \\
\text { Preparedness }\end{array}$ & 80 & 100 & 100 & 100 & 100 & 100 & 100 \\
\hline 79.13 & 80.40 & 81.51 & & & & & & \\
\hline
\end{tabular}

From the table above, it was shown that the performance of the Depok Health Office increased from 79.13 in 2013 to $81.51 \%$ by 2015 .

Bivariate analysis between independent and dependent variable was done using the correlation test and the result was further explained on the table below:

The result showed that therevwas a significant positive relationship between the percentage of budget allocation activities of UKM and Depok Health Office performance with $r=0.998$ (strong correlation) and $p$-value $=0.038$. Therefore, this research showed 
TABLE 4: Correlation between Percentage of budget allocation activities of UKM and Depok Health Office performance in $2013-2015$.

\begin{tabular}{l|cc}
\hline Independent Variable & \multicolumn{2}{|c|}{$\begin{array}{c}\text { Dependent Variable (Depok } \\
\text { Health Office performance } \\
2013-2015)\end{array}$} \\
\hline $\begin{array}{l}\text { Percentage of budget allocation } \\
\text { activities of UKM }\end{array}$ & r & p-value \\
\hline
\end{tabular}

that the higher the percentage of the budget allocation for the UKM, the performance of the Health Office was reached.

\section{Discussions}

Health office as organizer of health at the district/city level has benchmark performance called Minimum Service Standards (SPM). The performance of a health program is determined by the adequacy of operational budget and budget activities directly.

These studies and a researched by Wuri (2012) only looked at the allocation of Depok government budget in health services, amounting to $6.83 \%$ for the health service, but had not seen a quantity $10 \%$ according to the recommendation of Health Legislation. Health budget was not limited in the District health office, but it was divided into the other government offices (OPD) such as RSUD, BPMK, and other offices.

Based on the source of the budget, although the amount of funding provided to the District Health Office was increasing, the channeling of funds from the Central and provincial governments made the Depok Government turned out to reduce the percentage of the amount of the budget of APBD from 70.08\% in 2013 to $63.60 \%$ in 2015. An earmarked tax such as smoking tax, and DBHCT in which $50 \%$ of the appropriations, should be in the health sector. Adding JKN fund was the reason to reduction health budget inAPBD. This was related to the realization of the budget while the total number of human resources in the health service was very restricted to carry out program activities. (Suhandi Lubis 2013, Gani 2007)

From the above research, propensity for physical financing was still considerable, shown by $30 \%$ of the budget allocation was in supporting efforts (health systems strengthening) because of the needs of infrastructure and health equipment. UKP financing still absorbed over $50 \%$ of the budget. Non APBD fundings werer utilized for activities that were able to leverage the program's coverage into UKM, from about $12 \%$ to $18 \%$ of the budget as it was evidenced by the increase in the coverage of the indicators contained in the SPM reaching $81.51 \%$ of the targets to be achieved. Although Siti Sundari (2006) said that budget allocation was unenforceable because UKM and 
UKP was an inseparable or continuum program, a commitment to increase the budget for financing the activities of UKM could improve the performance of the district health office.

This research was observational research. Limitations of this research data were taken from budget allocation and just sort of activity-based budgeting program of Depok Health Office. Depok Government had not used the method of DHA (District Health Accounts) in drawing up health financing policy. The existence of this research might be the basic interests to develop DHA in Depok, so it could be known whether the costs were already allocated effectively and efficiently.

\section{Conclusions}

It could be concluded that to raise the performance of the required health service, the budgets should be sufficient to finance health programs. The performance of the health service could be seen from the coverage of the achievement of a minimum service Standards (SPM). The existence of a commitment to increase UKM financing was proven to be able to raise the coverage of indicators of SPM.

\section{Suggestions}

1. District Health Office should socialize Primary Health Care Provider (Puskesmas) how to make financial planning based on SPM so that the performance of the District Health Office could increase.

2. The Government of Depok City should develop health-based planning of DHA (District Health accounts) so that the allocation of funding could be effective and efficient.

\section{Acknowledgments}

Authors thank to Depok health Office particularly PEP and finance department, Bappeda Depok for the provision of data, Narita as data analysts, friends in magister FKM University Indonesia FKM, my families and my best friend who has been giving good support material as well as immaterial so that this paper can be realized. 


\section{References}

[1] Pusat Pembiayaan dan Jaminan Kesehatan Kementerian Kesehatan RI.2016. Modul dan Pedoman Pelatihan District Health Account (DHA).

[2] Wuri Noviyanti. 2013. Analisis Proses Penetapan Alokasi Anggaran Kesehatan pada Anggaran Pendapatan dan Belanja Daerah (APBD) Kota Bogor tahun 2012. Skripsi. Universitas Indonesia.

[3] Suhandi Lubis. 2013. Studi Pembiayaan setelah Program BOK DanPengaruhnya terhadap Cakupan Pelayanan Kesehatan Dasar Tahun 2010-2012 di Kabupaten Pasaman Barat: Studi Kasus 4 Puskesmas. Tesis. Universitas Indonesia.

[4] Ascobat Gani, et al. 2007. Institutionalization of NHA: Study Report to Bappenas. Jakarta.

[5] Siti Sundari. 2006. Studi Perbandingan Ideal Anggaran Upaya Kesehatan Masyarakat (UKM) Dan Upaya Kesehatan Perorangan (UKP) Di Tingkat Kabupaten/Kota. Laporan Akhir Penelitian. Badan Penelitian dan Pengembangan Kesehatan Departemen Kesehatan.

[6] http://docplayer.info/402090-Konseptual-rpjmn-bidang-kesehatan-tahun-20152019-kepala-biro-perencanaan-dan-anggaran-drg-tini-suryanti-suhandi-m-kes.html (accessed 18 September 2016).

[7] http://aiphss.org/id/health-financing-increasing-the-effectiveness-of-healthfinancing/ (accessed 20 September 2016).

[8] http://hapsafkmui.tumblr.com/post/114845799178/evaluasi-subsistem-pembiayaankesehatan (accessed 20 September 2016).

[9] https://www.academia.edu/5837697/Sistem_Pembiayaan_Nasional_dan_Penyusunan_Ang Kesehatan (accessed 25 September 2016).

[10] Undang-Undang Nomor 36 tahun 2009 tentang Kesehatan.

[11] Undang-Undang Nomor 23 tahun 2014 tentang Pemerintah Daerah

[12] Peraturan Presiden Nomor 72 tahun 2012 tentang Sistem Kesehatan Nasional.

[13] Peraturan Pemerintah Nomor 65 tahun 2005 tentang Pedoman Penyusunan dan Penerapan Standar Pelayanan Minimal

[14] Peraturan Pemerintah Nomor 38 tahun 2007 tentang Pembagian Urusan Pemerintahan antara Pemerintah, Pemerintahan Daerah Provinsi, dan Pemerintahan Daerah Kabupaten/Kota.

[15] Permenkes Nomor 741 tahun 2008 tentang Standar Pelayanan Minimal Kabupaten/Kota.

[16] Kepmenkes Nomor 4 tahun 2003 tentang Kebijakan dan Strategi Desentralisasi Bidang Kesehatan. 
[17] Kepmenkes Nomor 828 tahun 2008 tentang Petunjuk Teknis SPM Kabupaten/Kota.

[18] Kepmenkes Nomor 317 tahun 2009 tentang Petunjuk Teknis Perencanaan Pembiayaan SPM Bidang Kesehatan. 